\title{
The Influence of Athletic Learning Model on Improving Physical Fitness
}

\author{
Despita Antoni ${ }^{1 *}$, Dessi Novita Sari $^{2}$, and Sefri Hardiansyah ${ }^{3}$ \\ ${ }^{1,2,3}$ Faculty of Sports Sciences, Universitas Negeri Padang Padang, Indonesia \\ *Corresponding author. Email: despitaantoni@gmail.com
}

\begin{abstract}
Physical fitness describes a person's health level for various types of physical activity. Based on observation and research conducted on elementary school students, it was found that the level of physical fitness of elementary school students is still relatively low. This is thought to be caused by monotonous physical education learning. The purpose of this study is to determine the effect of the athletic learning model through varied and fun games on improving physical fitness of students at the State Elementary School 11 Kampung Jawa, Solok City. This research uses The One Group Pretest-Postest Design. The results of the research showed that there was an influence of the athletic learning model on the improvement of student's physical fitness which was marked by the initial average level of physical fitness of male students was 11.94 and the final average of 14.78 with $t_{\text {count }} 7.001>t_{\text {table }} 2.110$ and an increase in female students with an average the beginning was 12.17 and the final average was 14.22 with $t_{\text {count }} 5.219>t_{\text {table }} 2.110$ at the significance level $\alpha=0.05$.
\end{abstract}

Keywords: Athletic learning model, physical fitness levels

\section{INTRODUCTION}

Education is one of the main pillars embedded in national development. Through education we can prepare good quality of human resources. In accordance to the National Education System Law in Chapter II article 3 of the Law of the Republic of Indonesia No. 20 of 2003 [1] stating that:

The national education functions to develop capabilities and shape the citizen's characters as well as civilized society in an attempt to educate the citizens, aiming at developing the student's potential to become human beings who are faithful, noble, healthy, knowledgeable, capable, creative, independent, democratic, and responsible citizens in God Almighty.

One of the government's programs in realizing the above educational goals is by fostering education in elementary schools. Elementary School Education is an educational institution that prepares students to continue their education to a higher level. The age of Elementary School is also often called an intellectual period or a period of harmony in school.

Viewed from subjects in elementary schools, physical education lesson is one of the subjects and study material comprised in the elementary school curriculum which aims to improve physical fitness, motor skills development, knowledge and behavior of active life and attitude sportsmanship through physical activities.
Based on the above statement, it can be interpreted that physical fitness has an important role in students' daily activities because good physical fitness is very much needed by students, both in pursuing the education process at school and in achieving achievements outside of school. However, it is revealed through the observation that only $1 \%$ of students graduating from Elementary School whose physical fitness was in a very good category, while only $14.8 \%$ of students fell into a good physical fitness category.

Furthermore, the results of research conducted by the Department of Sport Education in 2017 on 558 students in the city of Padang found that none of the students' physical fitness levels were in the good and very good category.

As for physical fitness in general is physical physical well-being, namely the ability of a person to do his daily work efficiently without causing significant fatigue so that he can still enjoy his free time. This is in accordance with Widiastuti's statement (2010:13) stating that physical fitness is a physical condition that describes the physical abilities, can also be interpreted the ability of a person to do a particular job quite well, without causing fatigue. And this opinion was also emphasized by Syahara (2010:162) [2] stating that physical fitness is the body's ability to carry out physical and psychological activities without suffering from an 
extreme fatigue and still has energy for other physical activities in filling up his leisure time.

From the above opinion it can be summarized that physical fitness is all one's ability to do their daily tasks without experiencing significant exhaustion and still have energy reserves to enjoy their leisure time and sudden needs.

The low level of physical fitness of students graduating from elementary school is thought to be caused by many factors. Among them are the quality of learning provided. This is confirmed by Mutohir in Gusril (2008: 4) [3] stating that the low level of physical fitness of students is a result of the poor quality of physical education teaching in elementary schools.

Thus the creative and innovative sports teacher needs to provide physical education teaching in schools, in this case the athletic learning model that is in accordance with the growth and physical development of elementary school students that contains elements of fun games, especially athletic teaching materials.

As it is known that athletic sports are a branch of individual sports, known as the mother of sports, because of the movements that exist in athletics persist in other sports, and it cannot be denied that athletic sports are very important in improving physical fitness, ability and quality speed, endurance, reaction to movement, both in other sports and in everyday life.

Humans, as living creatures, need motion, walking, running, throwing, jumping. Of all the motion carried out only walking and swinging is more dominant, even though the body really needs motion. For that we need to find a way out so that every human being moves.

Based on the explanation above, the teacher is expected to be able to make teaching plans in accordance with the growth and physical development of elementary school motoric students. As in the teaching process that will be carried out in the athletic field, the teacher looks for forms of teaching that lead to games that are tailored to the objectives to be achieved in the teaching and the most principle in teaching that will be given is the achievement of teaching objectives through play.

In planning a game in sports activities, several things need to be determined, namely:

1. Fun

2. Excited after doing

3. There are objectives to be achieved clearly

4. Discipline of correct movements

5. Make simple rules that must be obeyed which are explained before playing.

In athletic teaching, this situation has not been fundamentally fulfilled. Thus as a teacher trying to find a form of play that is fun for students, so that the expected goals are achieved well. And it is expected that the teachers in providing material so as not to focus on the material provided and are expected to modify the movements to be performed in the form of play. Modifications can be on all material in athletics. Not only for facilities and movements, but also for the number of tools and participants and movements that lead to learning objectives. As is well known, elementary school level students enjoy playing. Furthermore, learning must remain in accordance with the objectives to be achieved.

After understanding these provisions, a teacher will look for and determine games that are in accordance with the objectives of learning such as: black-green games that aim to practice concentration on star material. Furthermore, the game is chasing seated/ elephants looking for prey/ fishing fish that aims to run short distances. The next game is switching stars which aim to train students in relay material. In the jump material, the game material can be in the form of vampires chasing frogs, jumping in various directions, both sideways, forwards, backward vertically or horizontally with one leg or two legs, with a spine or without obstacles and a big throwing ball game which is raised by the teacher with small balls on the throwing material.

\section{METHODS}

This study employed One Group Pre test-Post test Design which was carried out on 11 Elementary School 11 in Kampung Jawa, Solok City. Type of sampling used in this research was Cluster Random Sampling technique, namely 36 people of students grade $\mathrm{V}$ consisting of 18 male and 18 female students. The instrument used was the Indonesian Physical Fitness Test. To determine the level of physical fitness of elementary school students, the Ministry of National Education (2010:4) states that the Indonesian Physical Fitness Test for Elementary School students (Ages 1012) include: 1) Speed test by running 40 meters; 2) Arm muscle strength test by hanging elbows; 3) Abdominal muscle strength test by lying in bed for 30 seconds; 4) Test for leg muscle explosive power with an upright jump; and 5) endurance test through 600 meters running.

Hypothesis testing in this study can be processed using descriptive and inferential statistics with the $t$ test formula with the formula:

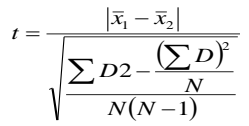

Information:

$t$ : Price of the $t$ test being sought 


\begin{tabular}{|c|c|c|c|c|c|}
\hline $\begin{array}{c}\text { Level of Physical } \\
\text { Fitness }\end{array}$ & Mean & $\mathbf{t}_{\mathbf{h}}$ & $t_{t}$ & $\begin{array}{c}\text { Significant } \\
\text { Tariff }(\alpha)\end{array}$ & $\begin{array}{c}\text { Test } \\
\text { Result }\end{array}$ \\
\hline Male's Pre-Test & 11,94 & \multirow{2}{*}{7.001} & \multirow{2}{*}{2.110} & \multirow{2}{*}{0,05} & \multirow{2}{*}{ Significant } \\
\hline Male's Post-Test & 14,78 & & & & \\
\hline $\begin{array}{c}\text { Female's Pre- } \\
\text { Test }\end{array}$ & 12,17 & \multirow{2}{*}{5,219} & \multirow{2}{*}{2,110} & \multirow{2}{*}{0,05} & \multirow{2}{*}{ Significant } \\
\hline $\begin{array}{c}\text { Female's Post- } \\
\text { Test }\end{array}$ & 14,22 & & & & \\
\hline
\end{tabular}

$\mathrm{X} 1$ : The 1st sample mean

Xz: Mean sample 2

D: Difference between sample scores 1 and 2

N: Couple

Df: Degrees of freedom $(\mathrm{df})=\mathrm{N}-1$

D: The sums are all different

D2: The sum of all squares that are squared

Source: Fardi (2010: 44) [4]

Before t-test analysis, the normalist test data is done through the Lilliefors test. because the $t$ test can only be used to test the mean difference of two samples taken from a normal population.

\section{RESULT AND DISCUSSION}

A. Result

Data of Normality Test

The results of the normality test using the Liliefors test on physical fitness data of State Elementary School 11 Kampung Jawa City students in Solok City can be seen in Table 1 summarizing the results of the following normality tests:

Table 1: Summary of Data Normality test

\begin{tabular}{|c|c|c|c|}
\hline $\begin{array}{c}\text { Body Well } \\
\text { Being }\end{array}$ & $\mathrm{L}_{\mathrm{o}}$ & $\mathrm{L}_{\mathrm{t}}$ & Conclusion \\
\hline $\begin{array}{c}\text { Male Pre } \\
\text { Test }\end{array}$ & 0,0570 & 0,200 & Normal \\
\hline $\begin{array}{c}\text { Male } \\
\text { Post Test }\end{array}$ & 0,1340 & 0,200 & Normal \\
\hline $\begin{array}{c}\text { Female } \\
\text { Pre Test }\end{array}$ & 0,0701 & 0,200 & Normal \\
\hline $\begin{array}{c}\text { Female } \\
\text { Post Test }\end{array}$ & 0,0814 & 0,200 & Normal \\
\hline
\end{tabular}

Based on table 1 above, it yields the data through the Liliefors test obtained the observation score of each variable (Lo < Lt with $\mathrm{n} 18$ and a level of $\alpha 0.05 \%$. If Lo is smaller than $\mathrm{Lt}$ this means that all data respectively each variable studied was normally distributed.

\section{Hypothesis testing}

The hypothesis proposed in this study is that there is an influence of the athletic learning model on improving physical fitness of students of the 11th Elementary School in Kampung Jawa, Solok City. To test the magnitude of the hypothesis correlation coefficient, an ttest analysis was performed with the following results:

Table 2: Summary of Hypothesis Testing Results for Physical Fitness Level of Elementary School Students 11 in Kampung Jawa, Solok City

Based on table 2 above, it is seen that there is an increase in the average physical fitness of male students from 11.94 to 14.78 with $t_{\text {count }}=7.001>t_{\text {table }} 2.110$, as well as an increase in the average physical fitness of female students from 12.17 to 14.22 with $t_{\text {count }}=5.219>$ $t_{\text {table }} 2.110$, with the results of the Ho test was rejected and $\mathrm{Ha}$ was accepted. This can be interpreted that the final data (post test) is better than the initial data (pretest). Hence, it is true that there is an influence of the athletic learning model on improving the Physical Fitness of Elementary School Students 11 in Kampung Jawa, Solok City.

\section{B. Discussion}

The hypothesis proposed in this study is that there is an influence of the Athletic learning model on improving the Physical Fitness of Elementary School Students 11 in Kampung Jawa, Solok City. The research findings reveal the athletic learning model designed in accordance to the growth and development of elementary school students with great joy/fun has a significant influence on the level of physical fitness of students.

After giving treatments to the students, it turns out that the average level of physical fitness of male students at the time of the pretest is 11.94 increased after being given an athletic learning model to 14.78 . Likewise, the average level of physical fitness of female students at the time of the pretest that is equal to 12.17 increased after being given an athletic learning model to 14.22. With the results of this study it can be stated that the given athletic learning model has an effect on the physical fitness level of Elementary School Students 11 in Kampung Jawa, Solok City. 0.05 for male student data. Likewise, the female students obtained the results of t-count of 5219 greater than t table 2.110 at the level of $\alpha=0.05$

As explained in the previous section that the teacher in providing athletic instruction must try to modify the material with various forms of fun games with direction, so that the expected goals are achieved well. Likewise modifying the means to be used.

\section{CONCLUSION}

Based on data analysis and the discussion that has been presented previously, it can be concluded that there is a significant effect of the athletic learning model on improving physical fitness of students of the 11th 
Elementary School in Kampung Jawa, Solok City. The initial average level of male students physical fitness of 11.94 increased to 14.78 after given a learning model with the results of the $t$-test analysis of $t_{\text {count }} 7.001>t_{\text {table }}$ 2.110. Likewise, the initial average level of female students physical fitness of of 12.17 , increased to 14.22 after being given an athletic learning model with the results of the t-test analysis, namely $t_{\text {count }} 2.219>t_{\text {table }}$ 2.110 .

\section{REFERENCES}

[1] Undang-Undang Republik Indonesia No 20 Tahun 2003 tentang Sistem Pendidikan Nasional

[2] Syahara, Sayuti. 2010. Metodologi Pengembangan Kemampuan Biomotorik. Padang: FIK UNP.

[3] Gusril. 2008. Model Pengembangan Motorik Siswa Sekolah Dasar. Padang: UNP Press

[4] Fardi, Adnan. 2010. Hand Out Statistik. Padang: FIK UNP. Jakarta: Sinar Grafika. 